\title{
Fungistatic activity of lactic acid bacteria isolated from silage
}

\author{
Fungistatyczna aktywność bakterii fermentacji mlekowej \\ wyizolowanych z kiszonek
}

\author{
Romuald Gwiazdowski ${ }^{1}$, Katarzyna Kluczyńska², Daniela Gwiazdowska ${ }^{2}$
}

\section{Summary}

The aim of this study was to isolate bacteria from silage based on corn or alfalfa and haylage, which are a rich source of lactic acid bacteria. During the experiments fungistatic properties against some pathogenic fungi belonging to Fusarium genus were evaluated. The present study examined 46 isolates from silage and haylage. Most of the lactic acid bacteria isolates reveal fungistatic activity against eight tested indicator strains. Results depended in a large extent on the species and strain of the fungus.

Key words: lactic acid bacteria, fungistatic properties, probiotics, silage

\section{Streszczenie}

Celem badań była izolacja bakterii z kiszonek na bazie lucerny i kukurydzy oraz sianokiszonki, które są bogatym źródłem bakterii fermentacji mlekowej. W doświadczeniach oceniono fungistatyczne właściwości bakterii mlekowych względem wybranych grzybów patogennych rodzaju Fusarium. W pracy przebadano łącznie 46 izolatów z badanych kiszonek i sianokiszonki. Większość izolatów bakterii fermentacji mlekowej wykazała aktywność fungistatyczną wobec ośmiu badanych szczepów wskaźnikowych. Wyniki zależały w dużym stopniu od gatunku i szczepu grzyba.

Słowa kluczowe: bakterie mlekowe, aktywność fungistatyczna, probiotyki, kiszonki

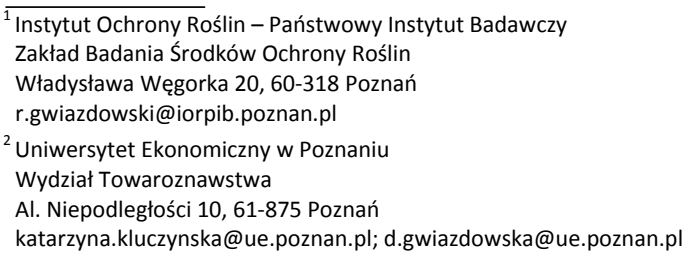




\section{Wstęp / Introduction}

W ostatnich latach obserwuje się wzrost zainteresowania biologicznymi metodami ochrony roślin, m.in. wykorzystaniem mikroorganizmów posiadających właściwości fungistatyczne. Wynika to z przekonania o rosnącym zanieczyszczeniu środowiska substancjami chemicznymi, a także, coraz bardziej widocznymi, ekologicznymi trendami w rolnictwie. Wszechobecność w uprawach roślin grzybów patogenicznych wymaga ich zwalczania tak, aby w jak najmniejszym stopniu wpłynęły na wielkość i jakość plonów. Poszukuje się drobnoustrojów wykazujących zdolność hamowania rozwoju grzybów, które mogłyby konkurować z chemicznymi środkami ochrony roślin lub wspomagać ich działanie, prowadząc jednocześnie do ograniczenia stosowania syntetycznych związków chemicznych.

W ciagu ostatnich dwudziestu lat opisano różne mikroorganizmy posiadające właściwości fungistatyczne, zarówno spośród bakterii, jak i grzybów. Można tu wymienić m.in. bakterie rodzajów: Bacillus, Pseudomonas, Enterobacter, grzyby zaliczane do rodzajów: Gliocladium, Trichoderma, czy promieniowce Streptomyces (Lange i wsp. 1993; Emmert i Handelsman 1999). Ich przydatność w biologicznym ograniczaniu występowania patogenów wynika ze zdolności do wytwarzania metabolitów antygrzybowych (Paulitz i Belanger 2001; Kloepper i wsp. 2004; Leclere i wsp. 2005), enzymów (Bull i wsp. 2002), czy współzawodnictwa z patogenami (van Dijk i Nelson 2000; Kageyama i Nelson 2003).

Najczęściej aktywne mikroorganizmy izoluje się ze środowiska naturalnego, jakim jest gleba. Dobrym źródłem są również komposty czy kiszonki, wykorzystane w niniejszej pracy. Te ostatnie stanowią dobre środowisko rozwoju bakterii fermentacji, które $\mathrm{z}$ jednej strony biorą udział w procesie zakiszania, a jednocześnie ich metabolity zabezpieczają kiszonki przed rozwojem niekorzystnych mikroorganizmów, w tym grzybów. Bakterie mlekowe to szeroko rozpowszechnione mikroorganizmy, które wykorzystywane są na dużą skalę jako naturalne środki owłaściwościach konserwujących. Bakterie te posiadaja status GRAS (generally recognised as safe), co oznacza, że zaliczane są do bezpiecznych dla zdrowia ludzi i zwierząt, ponadto cechuje je zdolność do produkcji licznych metabolitów o właściwościach przeciwdrobnoustrojowych (Schlegel 2005). Ich potencjał przeciwdrobnoustrojowy może być wykorzystany również jako element ochrony roślin przed patogenicznymi grzybami, m.in. rodzaju Fusarium. Grzyby te są wymieniane jako jedne $z$ najpowszechniej występujących w naszych warunkach klimatycznych, a zarazem powodujących straty ekonomiczne w uprawach. Należy przy tym podkreślić ich toksynotwórczość. Wytwarzane przez nie mikotoksyny stanowią duże zagrożenie przedostając się wraz z zanieczyszczonym materiałem roślinnym do żywności, ponieważ mają one zróżnicowane działanie, m.in. rakotwórcze. Przy długotrwałym narażeniu organizmu gospodarza na działanie mikotoksyn, już małe ilości tych substancji mogą mieć właściwości kancerogenne, teratogenne, czy też mutagenne.
W prezentowanej pracy przeprowadzono izolację bakterii mlekowych $\mathrm{z}$ kiszonek i określono ich fungistatyczny potencjał wobec różnych gatunków grzybów należących do rodzaju Fusarium.

\section{Materiały i metody / Materials and methods}

\section{Material badawczy}

Przedmiot badań stanowiło 46 szczepów bakterii fermentacji mlekowej, wyizolowanych z kiszonek z lucerny i kukurydzy oraz z sianokiszonki. Izolacja i identyfikacja naturalnych szczepów bakterii mlekowych została przygotowana na podstawie metod opisanych przez Trojanowską i wsp. (2009) oraz Huili i wsp. (2011).

Jako mikroorganizmy wskaźnikowe wykorzystano 7 gatunków grzybów rodzaju Fusarium, w tym: $F$. avenaceum, F. culmorum, F. equiseti (dwa izolaty), F. graminearum, F. langsethiae, F. oxysporum, F. poae. Grzyby pochodziły z kolekcji Zakładu Badania Środków Ochrony Roślin Instytutu Ochrony Roślin - Państwowego Instytutu Badawczego w Poznaniu.

\section{Izolacja bakterii fermentacji kwasu mlekowego}

Izolację bakterii mlekowych przeprowadzono pobierając 5 g poszczególnych kiszonek lub sianokiszonki do $200 \mathrm{ml}$ jałowej soli fizjologicznej. Z przygotowanej zawiesiny sporządzano szereg rozcieńczeń i posiewano metodą płytkową Kocha stosując pożywkę MRS agar (De Man Rogosa Sharpe Agar). Inkubację prób prowadzono w atmosferze beztlenowej w temperaturze $37^{\circ} \mathrm{C}$ przez 48 godzin. Po zakończeniu inkubacji izolowano bakterie, wybierając wyraźnie oddzielone kolonie o morfologii charakterystycznej dla bakterii kwasu mlekowego i przeszczepiano je na podłoże płynne MRS. Tak otrzymane izolaty poddawano wstępnej identyfikacji na podstawie morfologii oraz cech fenotypowych.

Określanie fungistatycznych właściwości bakterii mlekowych

Aktywność fungistatyczną wyizolowanych szczepów bakterii fermentacji mlekowej określano metodą dyfuzji studzienkowej. Zawiesiny zarodników wybranych gatunków grzybów rodzaju Fusarium rozprowadzano w jałowej soli fizjologicznej, następnie wysiewano je na pożywkę PDA (Potato Dextrose Agar) metodą zalewową. W dalszym etapie, korkoborem wycinano studzienki o średnicy $7 \mathrm{~mm}$. Do przygotowanych $\mathrm{w}$ ten sposób studzienek wprowadzano po $100 \mu \mathrm{l}$ 24-godzinnej hodowli izolatów bakterii mlekowych. Inkubacja trwała 10 dni w temperaturze pokojowej (około $20^{\circ} \mathrm{C}$ ). Po zakończeniu inkubacji mierzono strefy zahamowania wzrostu w mm. Wyniki przedstawiono jako średnią $\mathrm{z}$ trzech powtórzeń. Dla uzyskanych średnich policzono odchylenie standardowe.

\section{Wyniki i dyskusja / Results and discussion}

Bakterie wyizolowane $\mathrm{z}$ sianokiszonki oznaczono jako S1-S13, z lucerny: A1-A10, L1-L13, G1-G15, a z kiszonek 


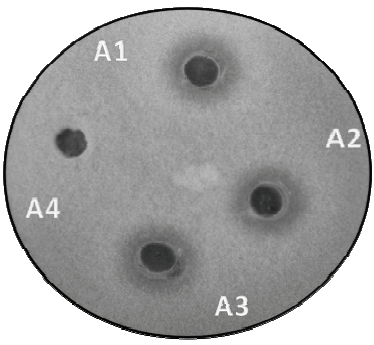

F. poae

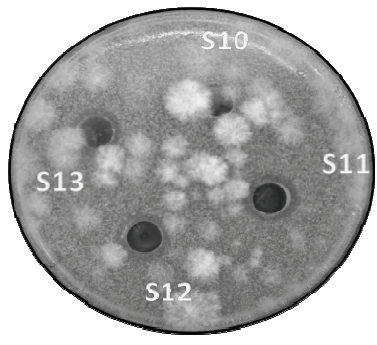

F. avenaceum

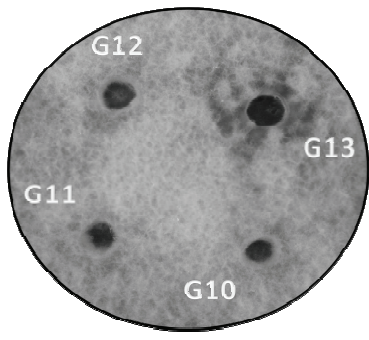

F. equiseti (I)

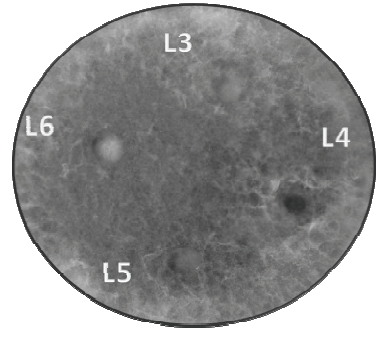

F. culmorum

Rys. 1. Fungistatyczne właściwości wybranych szczepów bakterii wobec grzybów rodzaju Fusarium

Fig. 1. Fungistatic properties of selected bacteria strains towards fungi of Fusarium genus

Tabela 1. Oddziaływanie wybranych szczepów bakterii na wzrost wyselekcjonowanych grzybów rodzaju Fusarium (strefa oddziaływania podana $\mathrm{w} \mathrm{mm}$ )

Table 1. The influence of the selected bacterial strains on the growth of chosen fungi f Fusarium genus (inhibition zone determined in mm)

\begin{tabular}{|c|c|c|c|c|c|c|c|c|}
\hline \multirow{2}{*}{$\begin{array}{l}\mathrm{Nr} \text { izolatu } \\
\text { No. isolate }\end{array}$} & \multicolumn{8}{|c|}{$\begin{array}{l}\text { Wielkość stref zahamowania wzrostu grzybów } \\
\text { The size of inhibition zones of fungal growth } \\
{[\mathrm{mm}]}\end{array}$} \\
\hline & $\begin{array}{l}F . \text { grami- } \\
\text { nearum }\end{array}$ & F. langsethiae & F. avenaceum & F. oxysporum & F. culmorum & F. equiseti (I) & F. poae & F. equiseti (II) \\
\hline $\mathrm{A} 1$ & $0,0 \pm 0,0$ & $1,0 \pm 0,0$ & $1,5 \pm 0,6$ & $1,0 \pm 0,9$ & + & + & 3,5 & $1,0 \pm 0,1$ \\
\hline $\mathrm{A} 2$ & $0,0 \pm 0,0$ & $1,0 \pm 0,0$ & $2,0 \pm 0,1$ & + & + & + & $3,0 \pm 0,0$ & $1,0 \pm 0,1$ \\
\hline A3 & $0,0 \pm 0,0$ & $1,5 \pm 0,5$ & $1,1 \pm 0,9$ & $2,0 \pm 1,0$ & + & + & $2,5 \pm 0,6$ & $1,0 \pm 0,0$ \\
\hline $\mathrm{A} 5$ & $0,0 \pm 0,0$ & $2,0 \pm 1,1$ & + & + & $0,0 \pm 0,0$ & + & $2,0 \pm 0,1$ & $1,0 \pm 0,1$ \\
\hline $\mathrm{A} 6$ & $0,0 \pm 0,0$ & $1,5 \pm 0,6$ & $0,0 \pm 0,0$ & + & $0,0 \pm 0,0$ & $0,0 \pm 0,0$ & $1,0 \pm 0,1$ & $1,0 \pm 0,1$ \\
\hline A7 & $0,0 \pm 0,0$ & $2,0 \pm 1,1$ & + & $1,0 \pm 0,1$ & + & $2,0 \pm 1,0$ & $1,0 \pm 0,1$ & $2,5 \pm 0,6$ \\
\hline $\mathrm{A} 8$ & $0,0 \pm 0,0$ & $3,0 \pm 0,0$ & + & $1,5 \pm 0,5$ & + & $1,0 \pm 0,1$ & $1,5 \pm 0,6$ & $2,5 \pm 0,6$ \\
\hline A9 & $0,0 \pm 0,0$ & + & $0,0 \pm 0,0$ & $1,0 \pm 0,0$ & $0,0 \pm 0,0$ & + & $2,0 \pm 0,0$ & $1,0 \pm 0,0$ \\
\hline $\mathrm{A} 10$ & $0,0 \pm 0,0$ & $1,0 \pm 0,0$ & $0,0 \pm 0,0$ & $2,5 \pm 0,5$ & $0,0 \pm 0,0$ & + & $2,5 \pm 0,6$ & $0,5 \pm 0,5$ \\
\hline L1 & $0,0 \pm 0,0$ & $0,5 \pm 0,5$ & $0,0 \pm 0,0$ & $1,5 \pm 0,6$ & + & + & $1,0 \pm 0,8$ & $1,0 \pm 0,0$ \\
\hline $\mathrm{L} 2$ & $0,0 \pm 0,0$ & + & $0,0 \pm 0,0$ & $1,5 \pm 0,6$ & + & + & $2,5 \pm 0,6$ & $0,5 \pm 0,5$ \\
\hline L3 & $0,0 \pm 0,0$ & $2,0 \pm 0,0$ & $1,0 \pm 0,0$ & + & + & + & $2,5 \pm 0,6$ & $0,5 \pm 0,5$ \\
\hline L4 & $0,0 \pm 0,0$ & $1,5 \pm 0,6$ & $1,0 \pm 0,0$ & + & + & + & $1,5 \pm 0,6$ & $1,0 \pm 0,0$ \\
\hline $\mathrm{L} 5$ & $0,0 \pm 0,0$ & $1,5 \pm 0,6$ & + & $1,5 \pm 0,6$ & + & + & $1,5 \pm 0,6$ & + \\
\hline L6 & $0,0 \pm 0,0$ & $1,5 \pm 0,6$ & + & + & + & + & $1,5 \pm 0,6$ & $1,0 \pm 0,0$ \\
\hline L7 & $0,0 \pm 0,0$ & $6,5 \pm 0,6$ & $3,0 \pm 0,0$ & + & + & + & $2,5 \pm 0,6$ & $1,0 \pm 0,0$ \\
\hline L9 & $0,0 \pm 0,0$ & $6,5 \pm 1,7$ & $1,5 \pm 0,6$ & $2,0 \pm 0,3$ & + & + & $0,5 \pm 0,5$ & $2,5 \pm 0,6$ \\
\hline L10 & $0,0 \pm 0,0$ & $7,0 \pm 1,1$ & $1,5 \pm 0,6$ & $1,0 \pm 0,0$ & + & + & $2,0 \pm 0,1$ & $1,0 \pm 0,1$ \\
\hline G1 & $0,0 \pm 0,0$ & + & $2,0 \pm 0,0$ & $2,0 \pm 0,0$ & + & + & $0,5 \pm 0,5$ & + \\
\hline $\mathrm{G} 2$ & $0,0 \pm 0,0$ & $1,0 \pm 0,0$ & $1,0 \pm 0,6$ & $2,0 \pm 0,0$ & + & + & $1,0 \pm 0,1$ & + \\
\hline G3 & $0,0 \pm 0,0$ & $1,0 \pm 0,0$ & $0,0 \pm 0,0$ & $2,0 \pm 0,0$ & + & + & $0,5 \pm 0,5$ & $0,5 \pm 0,5$ \\
\hline G5 & $0,0 \pm 0,0$ & $0,5 \pm 0,4$ & $0,0 \pm 0,0$ & $0,5 \pm 0,5$ & + & $1,1 \pm 0,9$ & $1,5 \pm 0,6$ & + \\
\hline G7 & $0,0 \pm 0,0$ & $1,0 \pm 0,1$ & $0,0 \pm 0,0$ & $1,0 \pm 0,0$ & $0,0 \pm 0,0$ & $1,0 \pm 0,0$ & $1,0 \pm 0,0$ & + \\
\hline G12 & $0,0 \pm 0,0$ & $1,5 \pm 0,6$ & $2,0 \pm 0,0$ & + & + & + & $3,0 \pm 0,0$ & + \\
\hline G13 & $0,0 \pm 0,0$ & $8,5 \pm 0,6$ & $2,5 \pm 0,6$ & + & + & $1,1 \pm 0,9$ & $0,5 \pm 0,5$ & $1,0 \pm 0,1$ \\
\hline G15 & $0,0 \pm 0,0$ & $10 \pm 2,3$ & $1,5 \pm 0,6$ & $1,0 \pm 0,0$ & + & + & $1,5 \pm 0,6$ & + \\
\hline S3 & $0,0 \pm 0,0$ & $2,5 \pm 1,7$ & $0,0 \pm 0,0$ & $0,0 \pm 0,0$ & + & $2,0 \pm 0,0$ & $0,5 \pm 0,5$ & + \\
\hline S7 & $0,0 \pm 0,0$ & $6,5 \pm 1,7$ & $2,0 \pm 0,0$ & $0,0 \pm 0,0$ & + & $4,0 \pm 0,0$ & $1,5 \pm 0,6$ & + \\
\hline $\mathrm{S} 11$ & $0,0 \pm 0,0$ & $2,0 \pm 0,1$ & $2,5 \pm 0,6$ & $0,0 \pm 0,0$ & $0,0 \pm 0,0$ & + & $1,5 \pm 0,6$ & + \\
\hline $\mathrm{S} 12$ & $0,0 \pm 0,0$ & $1,5 \pm 1,7$ & $2,5 \pm 0,6$ & + & + & + & $2,0 \pm 1,1$ & $1,1 \pm 0,9$ \\
\hline $\mathrm{S} 13$ & $0,0 \pm 0,0$ & + & $2,5 \pm 0,6$ & $1,0 \pm 0,0$ & + & + & $1,0 \pm 0,0$ & $1,0 \pm 0,0$ \\
\hline
\end{tabular}

+- strefy oddziaływania na grzybnię powietrzną - inhibition zones of aerial mycelium 
na bazie kukurydzy: K1-K12 oraz C1-C12. Hodowle badanych szczepów na podłożu MRS charakteryzował wzrost zarówno powierzchniowy, jak i wgłębny, w obu przypadkach konsystencja kolonii określona została jako śluzowata. Analiza mikroskopowa ujawniła, że wszystkie izolaty wytypowane jako bakterie mlekowe, miały kształt pałeczek, jednak wykazywały znaczne zróżnicowanie pod względem długości, grubości i ułożenia komórek. Oprócz bakterii mlekowych, zaobserwowano także obecność licznych drożdży $w$ próbach kiszonki, ale analiza mikroskopowa pozwoliła na ich eliminację. Kolejne badanie, mające na celu określenie zdolności bakterii do wytwarzania katalazy pozwoliło wyeliminować 2 szczepy bakteryjne. Ostatecznie, pozostało 46 szczepów, poddanych dalszej charakterystyce. Katalazoujemne szczepy przebadane zostały w celu stwierdzenia ich zdolności do wytwarzania metabolitów typowych dla grupy bakterii fermentacji mlekowej, m.in. kwasu mlekowego i octowego. Doświadczenia potwierdziły produkcję przez izolaty badanych kwasów na zróżnicowanym poziomie. Z perspektywy ekonomicznego wykorzystania badanych naturalnych szczepów jest to znaczący wskaźnik decydujący o wysokim poziomie konserwacji i antybakteryjnych, fungistatycznych, czy też detoksykujących właściwościach. Dane literaturowe wskazują, że bakterie fermentacji mlekowej wykazują właściwości antybakteryjne i fungistatyczne wobec różnych mikroorganizmów (Grajek i Sip 2004; Rouse i wsp. 2007; Gwiazdowski i Gwiazdowska 2008; Franco i wsp. 2011). Badania wykazały, że bakterie fermentacji mlekowej mogą ograniczać rozwój grzybów patogenicznych, takich jak: Alternaria, Sclerotinia, Fusarium, Botrytis zarówno w badaniach laboratoryjnych, jak i polowych (Gwiazdowski i Gwiazdowska 2008).

Drugi etap badań polegał na określeniu fungistatycznych właściwości badanych bakterii. Mikroorganizmami wskaźnikowymi były gatunki grzybów, powszechnie występujące w naszej strefie klimatycznej, a zarazem często powodujące choroby roślin. Rezultaty badań przedstawiono w tabeli 1.

Na podstawie przeprowadzonych doświadczeń zaobserwowano zróżnicowane oddziaływanie bakterii mlekowych w stosunku do testowanych grzybów (rys. 1). Stopień hamowania wzrostu zależał w dużej mierze od gatunku grzyba, ale także od izolatu bakterii. Analiza wyników doświadczeń fungistatycznego oddziaływania badanych bakterii pozwoliła na selekcję najaktywniejszych izolatów. Wyniki 31 najsilniej działających szczepów bakterii, spośród 46 badanych, przedstawiono w tabeli 1. Podczas badań obserwowano wyraźne strefy hamowania wzrostu, jak również strefy, w których rozwój grzybni był wyraźnie ograniczony w stosunku do grzybni niepoddanej działaniu bakterii. Mierzalne strefy oddziaływania przedstawiono w milimetrach, a ponadto wyszczególniono strefy oddziaływania na grzybnię powietrzną $(+)$ lub ich całkowity brak (0). Pośród badanych grzybów największą wrażliwością na działanie bakterii mlekowych cechowały się gatunki: $F$. langsethiae, $F$. avenaceum i $F$. poae. Porównując wpływ badanych izolatów bakterii na wzrost grzybów wskaźnikowych, średnie oddziaływanie fungistatyczne zaobserwowano w przypadku gatunków $F$. oxysporum oraz $F$. equiseti. Najmniejszą wrażliwość na oddziaływanie bakterii mlekowych wykazywał gatunek $F$. culmorum, w przypadku którego zaobserwowano jedynie minimalne oddziaływanie hamujące rozwój grzyba. W przypadku niektórych gatunków grzybów zaobserwowano również zmiany barwy i struktury grzybni powietrznej. Jedynym spośród badanych grzybów, który nie wykazywał wrażliwości na działanie bakterii mlekowych było $F$. graminearum.

Z przeprowadzonych badań wynika, że możliwe jest wytypowanie mikroorganizmów, które będą mogły mieć praktyczne zastosowanie w biologicznej ochronie roślin przed grzybami rodzaju Fusarium, zarówno jako pojedyncze szczepy, jak również jako element złożonych biopreparatów.

\section{Wnioski / Conclusions}

1. Kiszonka paszowa z lucerny i sianokiszonka okazały się dobrym źródłem zróżnicowanych form bakterii fermentacji mlekowej.

2. Badane szczepy bakterii mlekowych wykazywały działanie fungistatyczne wobec $7 \mathrm{z} 8$ testowanych gatunków grzybów. Stopień zahamowania rozwoju mikroorganizmu wskaźnikowego zależał od gatunku i szczepu grzyba.

3. Izolaty bakterii fermentacji mlekowej pochodzace z kiszonki z lucerny charakteryzowały się silniejszymi właściwościami hamującymi wzrost grzybów rodzaju Fusarium, w porównaniu z bakteriami wyizolowanymi z sianokiszonki.

4. Fungistatyczna aktywność wybranych szczepów bakterii mlekowych może znaleźć potencjalne praktyczne zastosowanie w ochronie roślin przed grzybami rodzaju Fusarium.

\section{Literatura / References}

Bull C.T., Shetty K.G., Subbarao K.V. 2002. Interactions between Myxobacteria, plant pathogenic fungi, and biocontrol agents. Plant Dis. 86: 889-896.

Emmert E.A.B., Handelsman J. 1999. Biocontrol of plant disease: a (Gram-) positive perspective. FEMS Microbiol. Lett. 171: 1-9.

Franco T.S., Garcia S., Hirooka E.Y., Ono Y.S., dos Santos J.S. 2011. Lactic acid bacteria in the inhibition of Fusarium graminearum and deoxynivalenol detoxification. J. Appl. Microbiol. 111: 739-748.

Grajek W., Sip A. 2004. Biologiczne utrwalanie żywności z wykorzystaniem metabolitów bakterii mlekowych, bakterie fermentacji mlekowej, klasyfikacja, metabolizm, genetyka, wykorzystanie. Wydawnictwo Politechniki Łódzkiej, Łódź: 175-226. 
Gwiazdowski R., Gwiazdowska D. 2008. Oddziaływanie mieszanych kultur bakterii fermentacji propionowej i mlekowej na grzyby patogeniczne. [Impact of mixed bacterial cultures of propionic and lactic fermentation on pathogenic fungi]. Prog. Plant Prot./Post. Ochr. Roślin 48 (2): 719-723.

Huili P., Guangyong Q., Zhongfang T., Zongwei L., Yanping W., Yimin C. 2011. Natural populations of lactic acid bacteria associated with silage fermentation as detrmined by phenotype, $16 \mathrm{~S}$ ribosomal RNA and recA gene analysis. Systematic Appl. Microbiol. 34: $235-241$.

Kageyama K., Nelson E.B. 2003. Differential inactivation of seed exudates stimulation of Pythium ultimum sporangium germination by Enterobacter cloacae influences biological control efficacy on different plant species. Appl. Environ. Microbiol. 69: 1114-1120.

Kloepper J.W., Ryu C.M., Zhang S. 2004. Induce systemic resistance and promotion of plant growth by Bacillus spp. Phytopathology 94: $1259-1266$.

Lange L., Breinholt J., Rasmussen F.W., Nielsen R.I. 1993. Microbial fungicides -the natural choice. Pestic. Sci. 39: 155-160.

Leclere V., Bechet M., Adam A., Guez J.S., Wathelet B., Ongena M., Thonart P., Gancel F., Chollet-Imbert M., Jacques P. 2005. Mycosubtilin overproduction by Bacillus subtilis BBG100 enhances the organism's antagonistic and biocontrol activities. Appl. Environ. Microbiol. 71: 4577-4584.

Paulitz T.C., Belanger R.R. 2001. Biological control in greenhouse systems. Annu. Rev. Phytopathol. 39: 103-133.

Rouse S., Harnett D., Vaughan A., van Sinderen D. 2007. Lactic acid bacteria with potential to eliminate fungal spoilage in foods. J. Appl. Microbiol. 104: 915-923.

Schlegel H.S. 2005. Mikrobiologia ogólna. PWN, Warszawa, 2: 84-85, 344, 346, 351-352; 636 ss.

Trojanowska K., Giebel H. Gołębiewska B. 2009. Mikrobiologia żywności. Wydawnictwo Uniwersytetu Przyrodniczego w Poznaniu: $45-48,51-56,59-62,73,95 ; 96$ ss.

van Dijk K., Nelson E.B. 2000. Fatty acid competition as a mechanism by which Enterobacter cloacae suppresses Pythium ultimum sporangium germination and damping-off. Appl. Environ. Microbiol. 66: 5340-5347. 